\title{
T eaching Vocabulary Through Picture Cards in Islamic Elementary School A Case Study in Nida Suksa School, Thailand
}

\author{
Like Raskova Octaberlina ${ }^{1}$, Ida Fitri Anggarini ${ }^{2}$ \\ 1Universitas Islam Negeri Maulana Malik Ibrahim Malang, ${ }^{1}$ MI Miftahul Huda Ngadireso \\ 1like_raskova@yahoo.com, 2idafitrianggarini482011@gmail.com
}

\begin{abstract}
Nowadays, English as a subject learned at the primary school level is important towards students. This study was conducted aimed to know the influence of Picture Cards in teaching vocabulary to the third grade of Nida Suksa School, Thailand. The subjects of the research were students in the third grade. The researcher only took nine students out of different levels from a high level (3/1), middle level (3/2), and low level (3/3) - the instrument used by the researcher an interview. The result showed that the students still had difficulty in understanding the texts because having a lack of vocabulary, long texts, and limited time to analyze the text in answering the question. The students studied vocabulary through Picture Cards, and they learned vocabulary tests from the textbook. Furthermore, the finding of this study was: Picture Cards can increase and enrich their vocabulary and their knowledge. The implication of Pictures Cards can motivate students to understand the text. Therefore, they can understand many texts in vocabulary tests.
\end{abstract}

Keywords. Teaching Vocabulary; Picture Cards; English

\begin{abstract}
Abstrak. Dewasa ini, Bahasa Inggris merupakan mata pelajaran yang di sekolah dasar. Hal ini disebabkan karena pentingnya Bahasa Inggris terhadap siswa. Penelitian ini dilaksanakan bertujuan untuk mengetahui pengaruh dari Kartu Bergambar pada pengajaran kosakata pada siswa kelas 3 Nida Suksa School, Thailand. Sasaran dari penelitian ini adalah siswa kelas tiga. Peneliti hanya mengambil 9 siswa dengan kemampuan berbeda dari yang paling mahir (3/1), sedang (3/2) dan rendah (3/3). Intrument penelitian menggunakan wawancara. Hasil dari penelitian ini menunjukkan bahwa siswa masih merasa kesulitan dalam memahami teks bacaan karena kurangnya perbendaharaan kata, teks terlalu panjang dan kurangnya waktu untuk menganalisis terjemahan teks pada saat menjawab soal. Siswa belajar kosakata melalui Kartu Bergambar and mereka belajar tes kosakata dari buku teks. Lebih lanjut, hasil dari penelitian menunjukkan bahwa Kartu Bergambar meningkatkan dan memperkaya kosa kata siswa dan pengetahuannya. Implikasi dari Kartu bergambar dapat meningkatkan motivasi siswa dalam memahami teks. Oleh karena itu, siswa dapat memahami berbagai teks di tes kosakata.
\end{abstract}

Kata kunci. Pengajaran kosakata; Kartu Bergambar; Bahasa Inggris

Received : 17-06-2020

Revised : 10-07-2020
Approved : 24-07-2020

Published : 27-07-2020

Copyright $@$ Madrasah Jurnal Pendidikan dan Pembelajaran Dasar. All Right Reserved.

This is an open access article under the CC BY-NC-ND license

(http://creativecommons.org/licenses/by-nc-nd/4.0/).

Correspondence Address: like_raskova@yahoo.com

\section{A. INTRODUCTION}

Since all people know that English is a universal language that can be accepted in various parts of the world. English is one of the most widely used international languages by people in various countries as a means of communication. Besides, along with the development, the need for the use of English requires every non-English speaking country to include English in their learning curriculum in all levels of study to 


\section{MADRASAH}

Jurnal Pendidikan dan Pembelajaran Dasar

p ISSN: 1979-5599 | e ISSN: 2502-194X

P a g e | 27

pursue and compete with other countries. This learning curriculum starts from kindergarten to university level, just like in Thailand.

Thailand is a non-native country, just as Indonesia. In Thailand, English is taught as a foreign language, not English as second language. Most Thai people use Basa Thai or Melayu as their daily speaking. This caused a problem that most of the student is not familiar with English, and it is the challenge for the teacher to provide the best strategy or media for English learning, especially in primary levels.

In addition, Nida Suksa School is an Islamic elementary school located in Ban Koe Tae, Mueang-Songkhla, Songkhla, Thailand. As an Islamic elementary school, there are so many subjects being learned by the student, just like the primary level in Indonesia, including English subjects. The learning process of English in this school was private for each class. Some day, there are outdoor classes that focused on teaching vocabulary. As similar as most elementary schools in I ndonesia, Thailand teachers begin the English class by learning English vocabulary first, as it is believed that the children will find it easy to learn other language, skills such as listening, reading, writing, and speaking one of the most crucial parts of learning language is vocabulary.

Moreover, Elementary school is the first place or level for students to learn English formally, especially in Thailand. Also, the students learn the necessary aspect of English, which is English vocabulary. Vocabulary is critical to be mastered first since it is an essential means of conducting communication. Further, mastering vocabulary would be helpful for the students to assist them in comprehending the language being learned. Without vocabulary, nothing can be conveyed. Furthermore, it is revealed that the quality of someone's skill in English depends much on their quality and the quantity of vocabulary mastered, the more vocabulary they mastered, the easier they develop four language skills (listening, speaking, reading and writing).

Besides, vocabulary is a base skill that influenced the student's four English skills. For example, by mastering vocabulary, it is easier for the student to understand the task. By knowing the meaning of vocabulary or text, it will increase the student's interest in learning English. Thus, it will increase the student's vocabulary and other English skills. Meanwhile, vocabulary is unique to a content area as unique as fingerprints to a human being (Munir 2016). All people have their own style in pronouncing vocabulary. Therefore, teachers know they must do something with the language of their content areas, but they often have trouble with what they should do.

Consequently, they reduce instruction to routines that have withstood time and teacher-centered practice, directing students to look up, define, memorize, and use content-specific words in sentences. Content area vocabulary must be taught well enough to remove potential barriers to students for understanding of texts as well as to promote a long-term acquisition of the language of a content area. The organizing principle underscores the main premise of the chapter: teaching words well means giving students multiple opportunities to learn how words are conceptually related to one another in the material they are studying. In other words, vocabulary must be taught to the students in a certain period to make them understand the text. This specific period would be the first place of learning English, such as elementary school.

Moreover, in teaching vocabulary for primary level, it has needed various methods or media to increase the student's interest and participation. Therefore, for 
those arguments above, the objective of the research is to know the influence of Picture Cards towards teaching vocabulary in elementary school.

It seems necessary to provide a clear definition of the term vocabulary. Different definitions may be given for the term vocabulary regarding different viewpoints. However, one can generally define vocabulary as the knowledge of words and word meanings. Alternatively, someone else may define vocabulary as a list of words arranged in alphabetical order with their definitions. A word, in most linguistic analyses, is described as a set of properties or features; each word is the combination of its meaning, register, association, collocation, grammatical behavior, written form (spelling), spoken form (pronunciation), and frequency. To master a word is not only to learn its meaning but also to learn seven other aspects. All these properties are called word knowledge(Alizadeh, 2016).

Definitions of vocabulary, according to Cameron in (Alqahtani 2015) vocabulary, is one of the knowledge areas in language, plays a significant role for learners in acquiring a language(Santosa, Pratama, and Putra 2020). Vocabulary is a word that contains specific meaning related to the texts to understand the text easier and translate it, especially for Islamic elementary school that the students have low skill and lack vocabulary than the higher-level student. That is why teaching vocabulary is needed.

Moreover, (Hernawati 2015) states that vocabulary is the word that people understand both their meaning and usage. Someone must have sufficient vocabulary to understand what is read and heard, to speak, and write the right words that could be understood by others. Vocabulary is "one of component that is very important in mastering English skill another speaking, reading, writing, and listening. The higher the amount of vocabulary that we memorize, the faster we dominate English. Vocabulary is "a list of words, and sometimes a phrase, usually arranged in alphabetical may be categorized as having for separate, but largely overlapping components indicate how vocabulary is processed and how it is used. Each has the receptive and productive capacity, and within capacity, we processed and utilized both spoken and written language". From those arguments, the researcher states that vocabulary is a piece of basic knowledge for the student, the more they have a vocabulary, the more accessible language teaching for them.

Meanwhile, at first, it seems needed to define teaching. Teaching is an activity or process of transforming knowledge to help someone require changes and develops their skills, attitudes, ideas, and appreciations. They are influenced by affective, cognitive, and psychomotor domains. In the past, vocabulary teaching and learning were often given little priority in second language programs, but recently there has been a renewed interest in vocabulary and its role in learning and teaching(Munir 2016).

According to Brown in (Marzulina and Pitaloka 2018), teaching is showing or helping someone to learn how to do something, giving instructions, guiding in the study of something, providing with knowledge, causing to know or understand. Fajrina, states that teaching means to help and cause someone to know something or to do something. Besides, according to Moore, teaching is the actions of someone who is trying to assist others to reach their fullest potential in all aspects of development. Thus, definitions of teaching are how the teacher gives someone knowledge or trains someone to instruct. Teaching also gives some information on a subject matter to the students in the classroom (Marzulina and Dj 2019). 


\section{MADRASAH}

Jurnal Pendidikan dan Pembelajaran Dasar

p ISSN: 1979-5599 | e ISSN: 2502-194X

The researcher argues that teaching is a process to make the student know the new information, and they can practice it in daily life. For example, today, they know about new animal vocabulary. They will practice that vocabulary in their daily life, repeat and remember it until they master the vocabulary, or understand a text. All those arguments can be proposed to define teaching and teaching vocabulary.

Teaching vocabulary in school was essential to increase student's English skills. The teacher argued as an international language, English makes it more relaxing for people to communicate and to have interaction with other people from different countries (the researcher, the native teacher, and others) to understand science, technology, art, and culture; it is because most works of literature are written in English. Hatam, Sa, and Rajabi (2018) defines that Teaching Vocabulary is believed to be the cornerstone of language courses.

Vocabulary acquisition also remains a very active area of research with significant implications to inform practice, and it is assumed that growth in vocabulary takes place because of gains in language. Furthermore, successful vocabulary acquisition has been associated with strong reading ability with becoming more communicative, able, and skilled, among others. Therefore, knowing and mastering the English language through teaching vocabulary will give benefits to students. There is one component that has a significant influence on the skills that is called vocabulary.

Nurdini and Marlina (2017) argued that vocabulary is the base component that students need to master to be able in those language skills. However, vocabulary is not specially taught in teaching English in the classroom. Consequently, students lack knowledge about words, and it impacts their language skills. Compared with three other skills, reading is a fundamental and useful skill for language acquisition. Also, reading will let students deal with many texts and words. That is to say that reading will allow students to face words and gaining them will be suitable for their language competence. However, students often find unknown words in reading. It is because the language or vocabulary they encounter in the English text is often entirely new for them.

As a result, they tend to look up the word in the dictionary or ask the teacher directly rather than to find the meaning by themselves. Besides, students often look up a word in their dictionary and select the first entry, without considering the context related to the unknown word they found. Therefore, students need strategies to help them understand vocabulary through reading. Nevertheless, the teacher in Nida Suksa School prefers to implement picture cards as media in teaching vocabulary.

According to (Asyiah 2017), the role of vocabulary in learning a foreign language is inevitable. Rich Vocabulary will help students mastering English and its four vital skills, which are listening, speaking, reading, and writing. This importance is proven by Thanh Huyen \& Thi Thu Nga (2003, in Rouhani \& Purgharib 2013), who define vocabulary as a language element that links the four language skills, including listening, speaking, reading, and writing in learning a foreign language.

Related to Aisyah, (Manik and Christiani 2016) said, teaching vocabulary was essential. A vocabulary is a total number of words which with rules for combining them to make up a language. In the world of education, students are expected to master enough vocabulary to support their English skills. When the students have known 
enough vocabulary, it will help them to make their learning process go easier with the maximum result. However, the main problem faced by many students that they master only a small number of vocabularies that lower their English competence. Vocabulary is very crucial in language learning and one of the crucial factors in learning English, especially in teaching junior high school students.

Moreover, the teacher in this school agreed that teaching vocabulary was essential. It is because before the students master the four skills, they must know some vocabulary to support them in learning English. English Vocabulary, as one of the language skill elements, has a vital role for young learners in learning foreign languages (Syafrizal and Haerudin 2018).

According to (Alqahtani 2015), Vocabulary knowledge is often viewed as a critical tool for second language learners because a limited vocabulary in a second language impedes successful communication. Researchers such as Laufer \& Nation, Maximo, Read, Gu, Marion, and Nation and others have realized that the acquisition of vocabulary is essential for successful second language use and plays a vital role in the formation of complete spoken and written language skills.

In English as a second language (ESL) and English as a foreign language (EFL), learning vocabulary items play a vital role in all language skills (i.e., listening, speaking, reading, and writing). Furthermore, Rivers and Nunan (1991) in (Alqahtani 2015), argues that the acquisition of an adequate vocabulary is essential for successful second language use because, without an extensive vocabulary, we will be unable to use the structures and functions we may have learned for comprehensible communication.

Teaching Vocabulary in Thailand is different from Indonesia; Thailand has its own alphabetical that influence the student's understanding of English subject. Moreover, as a non-native country, English is not a daily language. Most of the students use Basa Thai or Thai Language, and it causes the problem in teaching vocabulary. Furthermore, there are different characters or skills of the student, and it called a challenge or problem for the teacher in Nida Suksa School in teaching vocabulary.

Based on the observation, the teachers implement trial and error media in which looking for the best media for teaching vocabulary. In this case, the teachers are demanded to be creative and innovative to increase the student's interest and ability to learn English. One of the teachers argues that the ways to make the objects of the vocabulary look real is through Picture Cards.

Related to the argument above, (Nasikhah et al. 2019) states that the Learning model of vocabulary that mostly used by some teachers is memorizing or translating word by word helped by dictionary. We must know that students, moreover young learners, have a fresh brain to memorize something. However, students will feel very bored when they learn something that is not their interest. The impression is that teacher forces students to always learning something, but the teacher cannot be students' best guide to find their interest. That is why teachers should be creative to teach students so that students will get meaningful learning and learn their interests by themself.

While discussing media, it will be better to know the definition of it to avoid wrong interpretation. According to (Naz and Akbar 2018), a medium (plural: media) is a channel of communication. The word is derived from Latin word meaning "between." The term refers to anything that carries information between a source and a receiver. The definition of media focuses on the use of technologies plus concepts and contexts. 


\section{MADRASAH}

Jurnal Pendidikan dan Pembelajaran Dasar

p ISSN: 1979-5599 | e ISSN: 2502-194X

Page | 31

Media are the means for transmitting or delivering messages, and in teaching-learning perspective delivering content to the learners, to achieve effective instruction.

Since everybody knows that media give many advantages in the learning process, many of the teachers consider implementing it in the class. Anderson in (Nasution 2019) classify media into ten types, such as Audio, Print, Audio Print, Silent Visual Projection, Silent Audio Visual Projection, Visual Motion, Audio Visual Motion, Physical Object, Human and Environment and the last one is Computer. The use of all those media is to deliver material to students in the class.

(Ahmad 2012) claims that with the help of hypermedia (e.g., World Wide Web), multimedia becomes a more powerful tool for language learning. He maintains that one of the advantages of using hypermedia for language teaching is that it provides learners with a more authentic learning environment, as, for example, listening can be combined with visual. Related to Jamal, Fhuri Mega said the critical thing to use media is to know the way to use it because it is used in the classroom to avoid student boredom (Megawati and Nuroh 2018).

There are (seven) types of instructional media (Sukmahidayanti 2015): things itself; pictures; course book; boards; OHP; flipcharts; and computer based-technology. Pictures and images are one of graphic materials examples that convey messages and information. In this case, the teacher implements picture cards as media in teaching vocabulary.

Picture cards are a card created by the teacher appropriate with the English lesson. In the third grade (3/1 for the high-level student, 3/2 middle level, and 3/3 low level), the title of the subject is about the disease or illness. So, the teacher makes that cards with the picture of the patient and vocabulary. The teacher drills the student in teaching vocabulary through picture cards. It can be each student or all students in the class. The teacher prefers to use these picture cards because it is something new for the student in teaching vocabulary. The form of the picture is exciting and charming. This media was implemented because the teacher would like to know that picture cards increase and enrich their vocabulary and their knowledge. The teacher wishes that the implication of pictures cards can motivate students to understand the text. Therefore, they can understand many texts in vocabulary tests.

Additionally, based on the arguments above, the use of media is needed. In this case, picture cards are used as media in English learning. The use of picture cards in Nida Suksa School is essential because this card can increase the interest of the student, improve their language skills, especially their vocabulary and their knowledge. Therefore, this picture card was implemented.

\section{B. METHOD}

A qualitative study is defined as a study that investigates the quality of relationships, activities, situations, or materials (Ma'rifat 2017). This method only describes the real case that happens in the field, as a qualitative study, which meant that in this study, all the data are collected in the form of the explanation, not number and described in narrative text. In this case, frequent from display data for qualitative research data in the past have been narrative. Furthermore, according to 
(Bogdan, C, and Biklen 1982), "qualitative research is descriptive, the data collected are in the form of words or picture rather than the number."

In this context, teaching vocabulary was taken place at Nida Suksa School, Thailand. The students that were involved in this research is the third grade. The researcher only took nine students in different abilities from a high level (3/1), middle level (3/2), and low level (3/3). Some procedures taken were: 1) Preparing; 2) Implementing; 3) Giving feedback. Teacher created the Picture Cards and took the student in each class and grouped them in a class. The teacher gave the text and asked them to translate and guess what do the words mean. Furthermore, the teacher interviewed them related to teaching vocabulary process. Then, the teacher drilled them with a picture card, repeat it, and memorize it. Then, carry out the same procedure.

The instrument used by the researcher was interview. The researcher used structured interviews and qualitative interviews. The structured interviews mean that the researcher is interviewing with a script. Meanwhile, the qualitative interview looks like a sudden interview, no script, and usually, the researcher has a good relationship with the informant (Robert 2011). Some procedures taken to analyze were compiling, disassembling, reassembling, interpreting, concluding.

\section{FINDING AND DISCUSSION}

Drawn upon the training given to learners, several procedures that can be highlighted in this study.

1. Preparing

In this phase, the teacher prepared the cards and took nine students in different abilities from a high level (3/1), middle level (3/2), and low level (3/3) and grouped them in one class. Nation (2018) wrote some vocabulary exercises that need to be carefully prepared in advance. These may be part of a coursebook and may be planned to cover an area of vocabulary systematically. The significant values of prepared exercises are that they can be made to cover an area of vocabulary systematically, and learners can do them independently of the teacher.

Most published books of prepared vocabulary exercises use the Teach, test, and mark format. That is some aspects of the words are taught, and then the learners do labeling, completion, rewording, classifying, correcting, or matching activities, which they later mark using an answer key. If such exercises are done in pairs or small groups, then there is an added opportunity for learners to learn from each other (Nation 2018).

Moreover, in this case, the teacher preparing the method and media in teaching vocabulary besides to know the result, the teacher would like to make them ready to join the class. This phase related to (Munir 2016), that in teaching vocabulary, a method is theoretically related to an approach, organized by design, and practically realized in the procedure. The method is the planning of language teaching, which is consistent with the theories. In other words, the method is procedural. He also states that there are general categories of methods in teaching English vocabulary are as follows:

a. Presentation. In the presentation method, a source tells, dramatizes, or otherwise discarnate information to learners. It is a one-way communication controlled by the source, with no immediate response.

b. Demonstration. In this method of instruction, learners view a real or life-like. Demonstrations may be recorded and played back utilizing media such as video, cards, or poster 


\section{MADRASAH}

Jurnal Pendidikan dan Pembelajaran Dasar

p ISSN: 1979-5599 | e ISSN: 2502-194X

c. Discussion. As a method, discussion involves the exchange of ideas and opinions among students or students and teachers. It can be used in small or large groups.

d. Drill and practice. In drill and practice, learners are led through a series of practice exercises designed to increase fluency in a new skill or to refresh an existing one. To be effective, the drill and practice exercises should include feedback to reinforce correct responses and to remediate errors learners might make along the way.

Therefore, in this context, the teacher will implement the Picture Cards as media in teaching vocabulary towards the third-grade students in Nida Suksa School, Thailand.

\section{Implementing}

The second phase of this research is implementation. After preparing the students, the teacher chooses one of the subjects in the third grade, the subject have chosen is illness. Furthermore, the teacher implements the traditional method in English learning, such as ask them to read the text, translate it, and remember it.

Moreover, in this phase, the teacher did not show and implement the picture cards. It is because the teacher would like to know the student's ability, especially in vocabulary mastery, without using picture cards. (Munir 2016) states in the argument above that some of methods in teaching English vocabulary such as drill and practice. In drill and practice, learners are led through a series of practice exercises designed to increase fluency in a new skill or to refresh an existing one. To be effective, the drill and practice exercises should include feedback to reinforce correct responses and to remediate errors learners might make along the way. In this case, the teacher asks them to repeat what the teacher said, drill it then translate the text. However, based on the observation in the class, the learning situation was different. Therefore, the teacher decided to implement picture cards. Here are the cards:

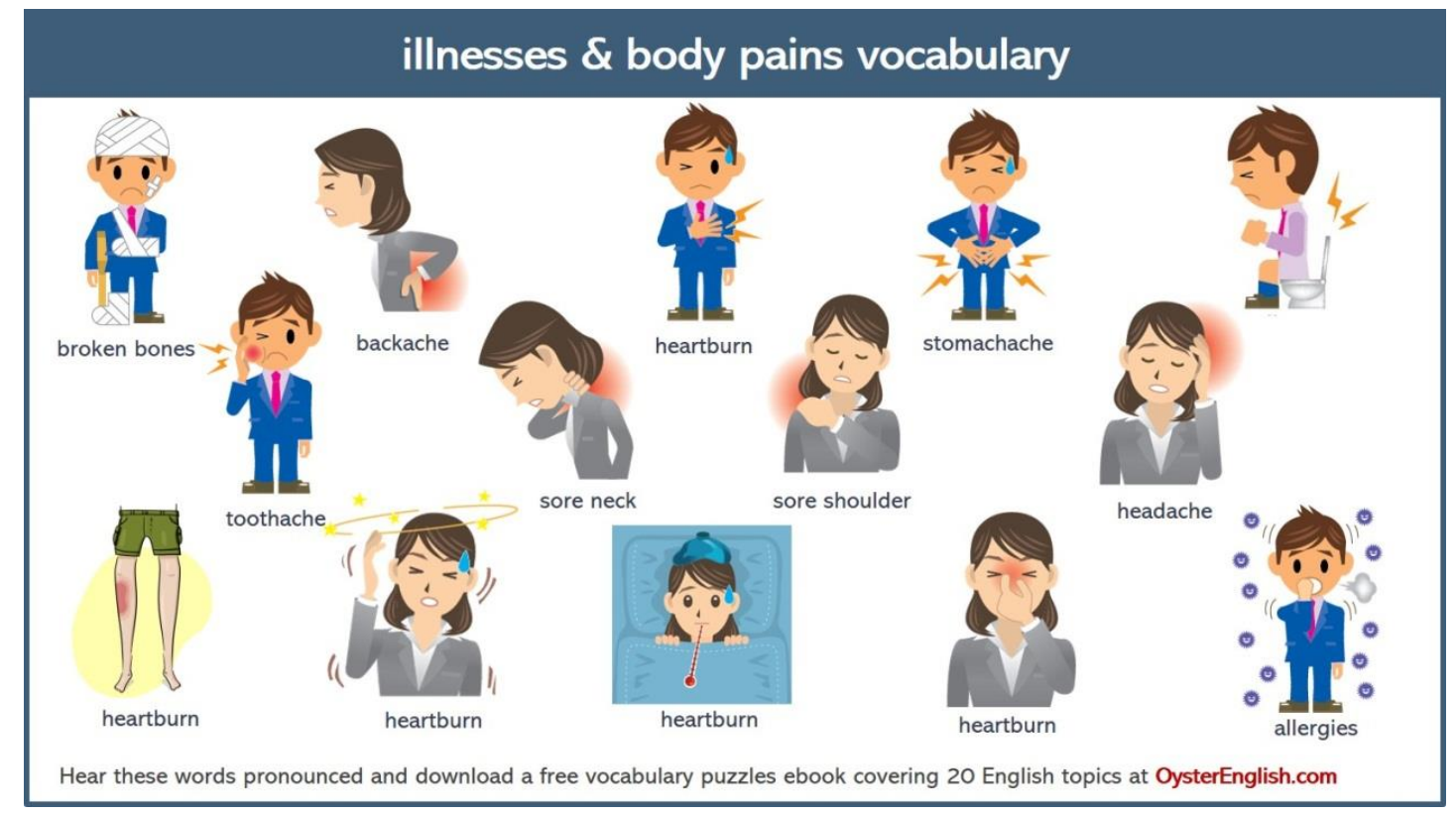

Picture A.1

The Example of Picture Cards 
After that, the teacher interviewed the student. Here is some of their answers.

Participant 1 - I think I've got confused, sometimes I mistranslate a text, can you tell me how does the way to learn English effectively?

Participant 2 - I feel bored teacher, I prefer studying science or math because $i$ don't know the meaning in learning English.

Participant 3 - Teacher, it is so difficult, I can't understand what does it mean. We speak Basa Thai every day, so it's a problem for us, we didn't know the meaning. English is difficult.

Participant 4 - I just answer the words that I memorized, I must memorize it well to increase my vocabulary, teacher. I can only memorize words slowly

Participant 5 - sometimes, I know the meaning, so I can understand. When I don't know the meaning, I pick a guess

Participant 6 - I just wonder how to learn vocabulary and understand the meaning of the text. I try to speak English everyday Teacher, to increase my vocabulary

Participant 7 - I don't know the meaning Teacher, it is difficult for me

Participant 8 - Since the Teacher teaches us, I feel better. I do hope I can learn English and I can speak English fluently. I am so sorry teacher if my mark isn't that right today.

Participant 9 - I try my best teacher, even I don't know some of the meaning. Thank you so much teacher for teaching in this class.

Surprisingly, they said that there is some trouble in teaching vocabulary such as feel troublesome, bored, and some of them did not know the meaning of several vocabularies, and soon. This one is related to (Asyiah 2017) that the importance of vocabulary and vocabulary mastery, however, is not sufficient to trigger the practice of ELT to give a greater emphasis on vocabulary teaching and vocabulary learning since it was found that the vocabulary teaching and learning seems to be neglected in learning English in Indonesia.

This seems unfortunate because for a country in which English is a foreign language, like Indonesia and Thailand, teaching English is very likely to face many obstacles and challenges and they mainly deal with vocabulary. For instance, in the comprehensive implementation of teaching English through Genre Based Approach (GBA), in which English is dominantly taught through several kinds of texts, students are inevitably required to read the texts and also understand what the texts are discussing about. In this stage, one of the most crucial problems that come up is that students are still lack of vocabulary.

Related to Asyiah, (Deni and Fahriany 2020) states that the several effective ways to teach young learners as it is mentioned below:

a. The teacher should be able to create enjoyable learning activities,

b. The teacher needs to create a comfortable situation so that the students does not need to worry about making a mistake and they are willing to try something, 


\section{MADRASAH}

Jurnal Pendidikan dan Pembelajaran Dasar

p ISSN: 1979-5599 | e ISSN: 2502-194X

P a g e $\mid 35$

c. The teachers need to perform words or materials with much action, picture, realia, and gesture,

d. The teachers should build an English-speaking class or make the students willing to talk in English,

e. Teachers should know that young learners like to play a game and sing songs

f. Teachers might try to tell a story with some properties and attractive voice,

g. Teachers should know that it is fine for the students to use their mother tongue sometimes,

h. Consistently recycle new language and add new things or to use words they will not know,

i. Teachers need to make a lesson plan with various activities.

For instance, the researcher states that providing enjoyable learning activities is needed. The teacher should create the best situation in the learning process to increase the student's interest and maximize the learning outcomes. The more they study easier, the more they understand the subject.

Moreover, for the next phase, the teacher uses picture cards in teaching vocabulary. The teacher drilled them with a picture card, give a quiz, repeat it, and memorize it. Then give the previous procedure. The result shows that Picture Cards can increase and enrich the student's vocabulary and knowledge. The implication of Pictures Cards can motivate students to understand the text. They said it is easier to memorize and understand the text through picture cards. Here are their answers:

Participant 1 - Teacher, thank you so much. I think it is easier for me to study English when implementing Picture Cards. The class feels different. I am so happy now.

Participant 2 - To be honest teacher, by implementing these cards now I knew some of the vocabulary. Even it's still hard for me. But I have to study harder teacher.

Participant 3 - Picture cards make me feel easier in learning English. I can memorize and understand the text. I suggest pictures cards is one of the best ways to learn vocabulary.

Participant 4 - By implementing these cards, I feel happy. I can understand the text more straightforward; the learning process experiences so much differences.

Participant 5 - it's easier for me to understand the text and increase my vocabulary by using these picture cards.

Participant 6 - Teacher, I like the way you teach us like that. I feel happy and understand the text. Thank you, teacher.

Participant 7 - I like these picture cards teacher, it is something new for me.

Participant 8 - Teacher, it is easier for me to understand the text and memorize the vocabulary. I am so happy; I've got the best score.

Participant 9 - As you know that teacher, this media (picture cards) give a different style in learning process, I'm so happy joinin this class. 
From their answer, we know that by implementing picture cards, it contains so many advantages for the students. They feel happy, understand the text, easier to know the meaning, and so on. Moreover, conversing about implementation, Here, the result is - Previous and Post Tests.

Table C.1. Previous Test

\begin{tabular}{rlc}
\hline No & Name & Score \\
\hline 1 & P 1 (3/1) & 7 \\
\hline 2 & P 2 (3/3) & 4 \\
\hline 3 & P 3 (3/2) & 5 \\
\hline 4 & P 4 (3/3) & 3 \\
\hline 5 & P 5 (3/2) & 4 \\
\hline 6 & P 6 (3/1) & 6 \\
\hline 7 & P 7 (3/3) & 3 \\
\hline 8 & P 8 (3/1) & 5 \\
\hline 9 & P 9 (3/2) & 5 \\
\hline
\end{tabular}

Table C.2. Post Test

\begin{tabular}{clc}
\hline No & Name & Score \\
\hline 1 & P 1 (3/1) & 10 \\
\hline 2 & P 2 (3/3) & 8 \\
\hline 3 & P 3 (3/2) & 9 \\
\hline 4 & P 4 (3/3) & 9 \\
\hline 5 & P 5 (3/2) & 8 \\
\hline 6 & P 6 (3/1) & 9 \\
\hline 7 & P 7 (3/3) & 10 \\
\hline 8 & P 8 (3/1) & 9 \\
\hline 9 & P 9 (3/2) & 10 \\
\hline
\end{tabular}

From the data above, it can be stated that Picture cards can increase and enrich the student's vocabulary. By using picture cards, the student can understand the text more, and enjoy English learning, and so on. For instance, related to (Deni and Fahriany 2020) the researcher agreed that various learning activities are needed. The teacher must be creative and innovative for providing the best learning atmosphere.

\section{CONCLUSION}

Teaching Vocabulary in Islamic elementary school or for young learners is crucial. It is because vocabulary has always been a fundamental skill to enable students to master four English skills, which are reading, writing, listening, and speaking. The more comfortable way to teach vocabulary in Islamic elementary school is by using creative media. One of the media that have been implemented is Picture card. Picture card is an exciting media that can be implemented for students in Islamic elementary schools to ensure the participation of the student and enable them to master vocabulary. Thus, by implementing picture cards, the teaching vocabulary process will be more advanced and straightforward.

\section{REFERENCES}

Ahmad, Jameel. 2012. "English Language Teaching ( ELT ) and Integration of Media 


\section{MADRASAH}

Jurnal Pendidikan dan Pembelajaran Dasar

p ISSN: 1979-5599 | e ISSN: 2502-194X

P a g e | 37

Technology." Procedia - Social and Behavioral Sciences 47 (Balaaco 1996): 924-29. https:/ / doi.org/10.1016/j.sbspro.2012.06.758.

Alizadeh, Iman. 2016. "Vocabulary Teaching Techniques: A Review of Common Practices" 1 (1): 22-30.

Alqahtani, Mofareh. 2015. "THE IMPORTANCE OF VOCABULARY IN LANGUAGE

LEARNING AND HOW TO BE TAUGHT" III (3): 21-34.

https:/ / doi.org/10.20472/TE.2015.3.3.002.

Asyiah, Dewi Nur. 2017. "THE VOCABULARY TEACHING AND VOCABULARY

LEARNING: PERCEPTION , STRATEGIES , AND INFLUENCES ON

STUDENTS'." Jurnal Bahasa Lingua Scientia 9 (2): 293-318.

Bogdan, Robert C, and Knop Sari Biklen. 1982. Qualitative Research for Education, An Introduction on Theory and Methods. London.

Deni, Rahma, and Fahriany. 2020. "Teachers' Perspective on Strategy for Teaching English Vocabulary to Young Learners" 9 (1): 47-60.

Hatam, Seyyed, Tamimi Sa, and Fereshte Rajabi. 2018. "Teaching and Learning Vocabulary: What English Language Learners Perceive to Be Effective and Ineffective Strategies Poučevanje in Učenje Besedišča: Katere so Uspešne in Neuspešne Strategije Po Mnenju Učencev Angleškega Jezika" 8: 139-63. https:/ / doi.org/10.26529/cepsj.492.

Hernawati. 2015. "Building up the Student's English Vocabulary Through Fanny Stories at SMP Negeri 2Duampanua Kab. Pinrang." Journal of English Language Teaching for EFL Learners 1 (2).

Ma'rifat, Dwi. 2017. "A Case Study of Using Songs in Teaching English Vocabulary to Young Learners." Journal of English and Education 5 (1): 49-55.

Manik, Sondang, and May Christiani. 2016. "TEACHING VOCABULARY USING MATCHING WORD ON COMPUTER ASSISTED, LANGUAGE LEARNING" 4 (7): $1-26$.

Marzulina, Lenny, and Muhammad Zuhri Dj. 2019. "The Case of Madrasah Students in South Sumatera Magnet Summary Strategy in Descriptive Writing :" 1 (1): 65-86.

Marzulina, Lenny, and Nova Lingga Pitaloka. 2018. "Looking at the Li Nk between Parents' Educational Backgrounds a Nd Students' English Achievement" 2 (1): 5160.

Megawati, Fhuri, and Ermawati Z Nuroh. 2018. "The Effect of English Subtitle Zootopia Movie in Speaking Skill" 5.

Munir, Fathul. 2016. "The Effectiveness of Teaching Vocabulary by Using Cartoon Film toward Vocabulary Mastery of EFL Students." Journal of English Language Teaching and Linguistics 1 (1): 13-37.

Nasikhah, Roikhatun, Udjang Pairin M Basir, Maskhurin Fajarina, and Universitas Hasyim. 2019. “Intensive Journal” 2 (2): 106-12.

Nasution, Abdul Khaliq R. 2019. "YouTube as a Media in English Language Teaching ( ELT ) Context: Teaching Procedure Text." Journal of Ultimate Research and Trends in Education 1 (1): 29-33.

Nation, Paul. 2018. "Teaching Vocabulary." ASIAN EFL Journal.

Naz, Ahsan Akhtar, and Rafaqat Ali Akbar. 2018. "Use of Media for Effective Instruction Its Importance : Some Consideration." Journal of Elementary Education A 
Publication of Deptt. of Elementary Education IER, University of the Punjab, Lahore Pakistan 18 (1-2): 35-40.

Nurdini, Husna, and Leni Marlina. 2017. "VOCABULARY JOURNAL AS A LEARNING TOOL FOR STUDENTS IN LEARNING VOCABULARY THROUGH READING." Journal of English Language Teaching 6 (1).

Robert, K Yin. 2011. Qualitative Research From Start To Finish. New York: The Guildford Press.

Santosa, MH, IPS Pratama, and INAJ Putra. 2020. "Developing Android Based English Vocabulary Learning Materials for Primary School Students." Journal of English Education and Linguistics Studies 7 (1): 164.

Sukmahidayanti, Tanti. 2015. "THE UTILIZATION OF INSTRUCTIONAL MEDIA IN TEACHING ENGLISH TO YOUNG LEARNERS ( A Case Study of an Elementary School Teacher in Bandung )" 3 (2): 90-100.

Syafrizal, and Haerudin. 2018. "The Implementation of Vocabulary Building Strategy in Teaching English Vocabulary to Young Learners." Journal of English Language Teaching 5 (1): 60. 